\title{
KORELASI MOTIVASI DAN HASIL BELAJAR IPA SISWA KELAS VIII DI SMP NEGERI SE-KECAMATAN JAMBI SELATAN
}

\author{
Wisnu Rahmad Saputra ${ }^{1}$, Menza Hendri ${ }^{2}$, Tugiyo Aminoto ${ }^{3}$ \\ ${ }^{1,2,3}$ Program Studi Pendidikan Fisika FKIP Universitas Jambi, Jambi, Indonesia \\ Email: wisnoesapoetra@gmail.com
}

\section{Info Artikel}

Diterima:

4November 208

Disetujui:

12 April 2019

Dipublikasikan:

30 Juni 2019

\begin{abstract}
Abstrak:
Tujuan penelitian ini untuk mengetahui hubungan motivasi dengan hasil belajar IPA siswa kelas VIII di SMP Negeri Se-Kecamatan Jambi Selatan. Penelitian ini menggunakan pendekatan kuantitatif dengan jenis korelasional. Variabel bebas yaitu motivasi belajar dan variabel terikat yaitu hasil IPA siswa. Instrumen pengumpulan data menggunakan angket motivasi belajar dan soal tes hasil belajar IPA materi Usaha dan Energi. Teknik analisis data terdiri dari uji normalitas, dan uji korelasi dengan taraf signifikasin 5\% dengan program SPSS. Hasil korelasi motivasi belajar dengan hasil belajar adalah 0,356 dengan sig 0,00 $<0,05$ maka $\mathrm{H}_{0}$ ditolak. Terdapat korelasi yang signifikan antara motivasi belajar dengan hasil belajar IPA pada siswa kelas VIII di SMP Negeri di Kecamatan Jambi Selatan.
\end{abstract}

Kata kunci: Korelasi, motivasi belajar, hasil belajar

\begin{abstract}
:
The purpose of this research was to know the correlation between motivation with the science learning outcomes of grade VIII students in SMP Negeri in South Jambi district. This research used quantitative approaches with correlational type. Independent variables were learning motivation and dependent variables were the science learning outcomes. Data collection instruments using motivational questionnaire and test of science learning outcomes of work and energy content. Data analysis techniques consist of test normality, and correlation test with a significance level of 5\% with the SPSS programe. The result of the correlation of motivation learning with the learning outcomes is 0.356 with SIG $0.00<0.05$ then $H_{0}$ rejected. There is a significant correlation between the motivation with the science learning outcomes in class VIII students in SMP Negeri in South Jambi district.
\end{abstract}

Keywords: Correlation, learning motivation, learning outcomes 


\section{Pendahuluan}

Perkembangan siswa seutuhnya menggambarkan adanya suatu perubahan dalam diri seseorang, baik itu perkembangan fisik, emosional, sosial, intelegensi maupun perkembangan spiritual yang saling berhubungan satu dengan yang lainnya. Pendidikan di sekolah lebih dikenal dengan sebutan proses belajar mengajar. Proses belajar mengajar ini terjadi dengan melibatkan banyak faktor, baik pendidik, siswa, bahan atau materi, fasilitas maupun lingkungan. Belajar harus direncanakan, disusun dan dievaluasi hasilnya, artinya bahwa berhasil tidak pencapaian tujuan pendidikan banyak tergantung pada proses belajar dan hasilnya.

Kegiatan belajar mengajar adalah inti kegiatan dalam pendidikan segala sesuatu yang telah diprogramkan akan dilaksanakan dalam kegiatan belajar mengajar. Semua komponen pengajaran akan berproses didalamnya. "Komponen inti yakni manusiawi, pendidik dan anak didik melakukan kegiatan dengan tugas dan tanggung jawab dalam kebersamaan berlandaskan interaksi normatif untuk bersamasama mencapai tujuan pembelajaran" (Djamarah, 2002). Dalam dunia pendidikan, bidang studi fisika diajarkan pada jenjang Sekolah Menengah Pertama (SMP). Fisika merupakan salah satu cabang ilmu pengetahuan alam yang tujuannya mempelajari gejala-gejala alam untuk mendapatkan produk fisika yang sifatnya khas dan bisa menjelaskan dari gejala alam itu sendiri. Suatu proses belajar-mengajar dikatakan baik, apabila proses tersebut dapat membangkitkan kegiatan belajar yang efektif, dan sasaran yang akan dicapai dari pembelajaran bisa terlaksana dengan baik, sehingga hasil belajar yang diinginkan bisa tercapai.

Salah satu aspek lain yang berpengaruh terhadap prestasi belajar siswa yang berperan penting dalam proses pembelajaran adalah motivasi belajar. Motivasi bersifat hasil belajar (learned), yaitu perubahan yang terjadi pada perubahan emosional yang diakibatkan oleh adanya stimulus dari luar. Motivasi merupakan perilaku ke arah suatu tujuan, dengan demikian motivasi merupakan pendorong seseorang untuk lebih giat berusaha untuk mencapai prestasi terbaiknya. Satu dari sekian cara untuk mempelajari motivasi adalah dengan mempertimbangkan faktor-faktor nonfisiologis yang mempengaruhi perilaku.
Menurut Budiadya (2006), dalam penelitiannya menemukan bahwa faktor motivasi belajar berpengaruh terhadap prestasi belajar fisika siswa. Pembahasan lebih lanjut dikatakan bahwa motivasi belajar terkait dengan dorongan untuk terlibat aktif dalam suatu kegiatan belajar, baik yang berasal dari diri siswa sendiri maupun dari luar diri siswa.

Hasil Observasi di lapangan yang dilakukan di ruang kelas VIII Se- Kecamatan Jambi Selatan pada pelajaran IPA dengan materi usaha dan energi dan menggunakan berbagai metode dan strategi pembelajaran. Kondisi yang terjadi di kelas ini siswa cenderung kurang aktif, tidak fokus dan sering bercanda, mereka terlihat tidak tertarik dengan pembelajaran yang sedang berlangsung. Interaksi siwa di dalam kelas pada saat presentasi berlangsung terkesan satu arah dan kurang hidup.

Melanjutkan pengamatan terkait ada beberapa faktor yang muncul dan terlihat ketika proses pembelajaran tersebut berlangsung dan memungkinkan menjadi penyebab siswa mengalami kesulitan dalam memahami materi pembelajaran fisika. Faktor tersebut diantaranya. Pertama, Siswa yang memiliki motivasi belajar akan lebih mudah dalam mencapai hasil belajar yang diinginkan namun yang terjadi masih banyak siswa yang belum memiliki motivasi belajar yang tinggi. Hal itu terlihat dari masih ada siswa yang malas belajar, tidak konsentrasi dalam menerima pelajaran, kurang semangat dalam belajar, tidak berani bertanya dan mengemukakan pendapatnya dan hanya beberapa siswa yang mengerjakan tugas sementara yang lain ribut padahal motivasi belajar erat hubungannya dengan hasil belajar siswa.

Kedua, Belajar membutuhkan sarana dan prasarana misal buku, peralatan sekolah, fasilitas sekolah masih kurang dalam memenuhi kebutuhan siswa terhadap keberadaan fasilitas sekolah. Misal jumlah gedung, ruang praktik, perpustakaan dan lain-lain. Sehingga dapat disimpulkan bahwa kekurangan sarana belajar menghambat pencapaian hasil belajar.

Ketiga, Hasil belajar siswa masih rendah yaitu sesuai dengan nilai ulangan semester ganjil yang di peroleh siswa, masih banyak siswa yang memperoleh nilai di bawah KKM < 2.69. Sedangkan Kriteria Ketuntasan Minimal (KKM) yang ditetapkan sekolah sesuai dengan kurikulum 2013 adalah > 2.69. 
Berdasarkan kenyataan bahwa hasil belajar yang dicapai siswa masih belum memuaskan bagi semua pihak. Secara umum memberikan gambaran bahwa nilai rata-rata kelas yang masih relatif rendah sehingga perlu adanya usaha dan upaya baik siswa maupun guru untuk meningkatkan hasil belajar mereka untuk mencapai tujuan yang dikehendaki baik siswanya maupun lembaga pendidikan.

\section{Metode Penelitian}

\section{Jenis Penelitian}

Penelitian ini termasuk penelitian deskriptif kuantitatif jenis korelasional. Penelitian deskriptif kuantitatif adalah penelitian yang dimaksudkan untuk menyelidiki keadaan, kondisi atau hal lain-lain dimana data yang di peroleh berupa angka-angka yang dianalisis menggunakan statistik. Penelitian korelasional adalah penelitian yang dilakukan oleh peneliti untuk mengetahui tingkat hubungan antara dua variabel atau lebih, tanpa melakukan perubahan, tambahan atau manipulasi terhadap data yang memang sudah ada (Arikunto, 2010).

\section{Waktu dan Tempat Penelitian}

Penelitian dilakukan di SMP Negeri seKecamatan Jambi Selatan pada semester ganjil tahun ajaran 2016/2017.

\section{Subjek Penelitian}

Subjek penelitian adalah siswa kelas VIII SMP Negeri se-Kecamatan Jambi Selatan, dan variabel yang di olah adalah motivasi belajar sebagai variabel bebas siswa dan hasil belajar sebagai variabel terikat.

Prosedur

Penelitian ini termasuk penelitian yang bersifat deskriptif kuantitatif jenis korelasional. Penelitian deskriptif kuantitatif adalah penelitian yang dimaksudkan untuk menyelidiki keadaan, kondisi atau hal lain-lain dimana data yang di peroleh berupa angka-angka yang dianalisis menggunakan statistik. Penelitian korelasional adalah penelitian yang dilakukan oleh peneliti untuk mengetahui tingkat hubungan antara dua variabel atau lebih, tanpa melakukan perubahan, tambahan atau manipulasi terhadap data yang memang sudah ada. Agar penelitian ini berjalan sesuai dengan semestinya, penelitian ini mengikuti alur yang telah di buat sebelumnya, yaitu :

\section{Observasi}

Sebelum melakukan penelitian penulis melakukan observasi pada siswa kelas VIII SMP Negeri Se-Kecamatan Jambi Selatan pada bidang studi IPA dan pokok bahasan fisika. Dan meninjau variabel yang ingin di teliti yaitu motivasi belajar dan hasil belajar fisika.

\section{Masalah \& Pembatasan Masalah}

Setelah melakukan observasi di lapangan penulis melihat banyak permasalahan yang terjadi, dan penulis mendata masalah yang sesuai dengan variabel yang ingin penulis teliti. Kemudian penulis membuat batasan-batasan agar permasalahan yang diteliti sesuai dengan variabel dan nantinya akan memiliki hasil yang vaild.

\section{Peta Konsep}

Setelah menentukan masalah dan pembatasan masalah penulis membuat dan menyusun peta konsep atau alur penelitian agar penelitian berjalan dengan benar dan tidak mengalami kesalahan yang fatal.

\section{Penyusunan Instrumen}

Setelah membuat peta konsep penulis memulai langkah penelitian dengan meyusun instrumen apa saja yang akan digunakan dalam penelitian, agar variabel penelitian dan masalah penelitian dapat di hubungkan dan di kalkulasikan.

\section{Validitas Instrumen}

Agar intrumen reliabel atau dapat digunakan dengan semestinya tentunya intrumen itu harus dilakukan uji validitas. Dan karena penulis menggunakan intrumen yang sudah pernah digunakan peneliti sebelumnya dengan hasil validitas tinggi maka penulis tidak lagi melakukan uji validitas intrumen.

\section{Pengumpulan Data}

Setelah melakukan pengujian instrumen penulis melakukan pengumpulan data di lapangan. Yaitu di SMP Negeri Se-Kecamatan Jambi Selatan dengan subjek siswa kelas VIII. Analisis Data

Setelah penulis melakukan pengumpulan data, penulis kemudian menganalisis data tersebut agar diperoleh hasil dari hubungan 
kedua variabel yang di teliti dengan teknik analisis yang sudah ditentukan.

\section{Penarikan Kesimpulan}

Setelah mendapatkan hasil dari pengolahan dan menganalisis data yang di dapat dari pengumpulan data dari lapangan. Penulis menarik sebuah kesimpulan penelitian dari variabel yang telah di teliti serta hubungannya dengan permasalahan yang terjadi di lapangan.

\section{Instrumen Penelitian}

Penelitian ini bersifat kualitatif yang digunakan adalah data tentang bagaimana korelasi ataupun hubungan antara motivasi belajar dengan hasil belajar kognitif. Untuk itu penelitian ini menggunakan instrument berupa angket berisi 25 pernyataan dengan 4 skala penilaian yaitu selalu, sering, jarang, tidak pernah. Disetiap kolompok nilai siswa hanya boleh memilih satu pilihan saja. Dari jumlah opsi pernyataan terbanyak yang dipilih oleh siswa akan disimpulkan berapa tinggi motivasi yang dimiliki oleh siswa. Angket atau kuesioner merupakan teknik pengumpulan data yang dilakukan dengan cara memberikan seperangkat pertanyaan atau pernyataan tertulis kepada responden untuk dijawabnya. Angket yang digunakan berbentuk ceklist dengan Skala Likert model skalalima. Skala Likert digunakan untuk mengukur sikap, pendapat, dan persepsi seseorang atau sekolompok orang tentang fenomena sosial yang disebut sebagai variabel penelitian (Sugiyono, 2009). Angket yang digunakanadalah angket yang sebelumnya telah digunakan Devi Elfrisa Nababan sebagai instrumen penelitian yang telah valid, dengan tingkat kevaliditasan yang sangat tinggi.

Instrumen kedua yaitu tes hasil belajar berupa soal, yang digunakan untuk mendapatkan data hasil belajar adalah berupa tes objektif. Tes objektif yang digunakan berupa pilihan ganda (Multiple Choise Test).

Proses perhitungan data hasil belajar siswa diperoleh dari pemberian testulis pada tahap evaluasi, dimana soal-soal berbentuk objektif dengan lima alternative pilihan.

\section{Teknik Analisis Data}

Teknik analisisnya adalah sebagai berikut: a) validitas angket, sebuah instrumen dapat dikatakan sudah valid apabila mampu mengukur apa yang diinginkan dan juga dapat mengungkapkan data dari variabel yang diteliti secara tepat. Perhitungan uji validitas dapat dilakukan dengan menggunakan program komputer yaitu SPSS 16.0. Dimana harga $r_{\text {hitung }}$ kemudian akan dikonsultasikan dengan $r_{\text {tabel }}$ pada taraf signifikansi 5\%. b) reliabilitas angket, menguji reliabilitas instrumen digunakan rumus Alfa Cronbach (Sugiyono, 2011), rumus ini digunakan karena pada angket atau kuesioner yang digunakan dalam penelitian ini tidak terdapat jawaban yang bernilai salah atau nol. Hal ini sesuai dengan rumus Alfa Cronbach yang dapat digunakan untuk mencari reliabilitas instrumen yang skornya bukan 1 dan 0 , misalnya pada angket atau jenis data yang berbentuk interval/essay yang dihitung dengan menggunakan IBM SPSS statistik 16.0 (Sugiyono, 2011).

Data yang dianalisis adalah data Motivasi siswa yang diperoleh dari instrumen angket dan data tes hasil belajar siswa yang diperoleh dari instrumen tes hasil belajar siswa. Data yang di analisis diperoleh dari motivasi siswa dalam lembar angket. Skor hasil angket jika siswa memilih Selalu point 4, Sering 3, Jarang point 2 Tidak Pernah point 1. Klasifikasi skor berdasarkan jumlah yang diperoleh dapat dihitung menggunakan rumus :

$$
\begin{aligned}
& \begin{array}{l}
\text { jarak interval }= \\
\text { skor tertinggi-skorterendah } \\
4
\end{array} \\
& =\frac{125-25}{4} \\
& =25
\end{aligned}
$$

Berdasarkan jarak interval diatas dapat disusun klasifikasi sikap motivasi siswa berdasarkan skor jawaban responden siswa sebagai berikut:

Tabel 3.4 Klasifikasi Sikap Skor Motivasi Belajar

\begin{tabular}{ll}
\hline Jumlah Skor Jawaban & Klasifikasi Sikap \\
$100 \mathrm{~s} / \mathrm{d} 125$ & SangatBaik \\
\hline $76 \mathrm{~s} / \mathrm{d} 100$ & Baik \\
$51 \mathrm{~s} / \mathrm{d} 75$ & Tidak Baik \\
$25 \mathrm{~s} / \mathrm{d} 50$ & Sangat Tidak Baik \\
\hline & Sumber : Data Pribadi
\end{tabular}

Selanjutnya untuk menentukan nilai perbedaan variasi data dilakukan Uji homogenitas untuk menguji apakah kelas sampel dalam populasi mempunyai variansi yang sama. Untuk melakukan uji homogenitas data diambil dari data hasil ujian mid semester genap siswa kelas VIII SMP Negeri se- 
Kecamatan Jambi Selatan tahun ajaran 2016/2017.

Untuk menguji kesamaan $\mathrm{k}$ buah ( $\mathrm{k} \geq$ 2) variansi kelas dalam populasi yang berdistribusi normal masing - masing dengan variansi $\sigma_{1}{ }^{2}, \sigma_{2}{ }^{2}, \sigma_{3}{ }^{2}$ diuji hipotesis :

$\mathrm{H}_{0}: \sigma_{1}{ }^{2}=\sigma_{2}{ }^{2}=\sigma_{3}{ }^{2}$

$\mathrm{H}_{l}$ : paling sedikit satu tanda sama dengan tidak berlaku.

Menghitung variansi gabungan dari semua kelas dalam populasi dengan rumus:

$s^{2}=\frac{\sum_{i=1}^{5}\left\{\left(n_{i}-1\right) \log s_{i}^{2}\right\}}{\sum_{i=1}^{5}\left(n_{i}-1\right)}$

Menghitung harga-harga satuan Bartlett (satuan B) dengan rumus:

$B=\left(\log s^{2}\right) \sum_{i=1}^{5}\left(n_{i}-1\right)$

Menentukan Chi Kuadrat hitung dengan rumus:

$X_{\text {hitung }}^{2}=(\ln 10)\left\{B-\sum_{i=1}^{5}\left(n_{i}-1\right) \log s_{i}^{2}\right\}$

dengan $\ln 10=2,3026$

Kriteria pengambilan keputusan berdasarkan pada:

Dengan taraf nyata $\alpha$, tolak Hipotesis Ho jika $X_{\text {hitung }}^{2} \geq X_{(1-\kappa)(k-1)}^{2}$, dimana $X_{\left(1-\frac{1}{2} \sigma\right)(k-1)}^{2}$ didapat dari daftar distribusi Chi Kuadrat dengan peluang $(1-\alpha)$ dan $\mathrm{dk}=(\mathrm{k}-1)$, jika $\quad X_{\text {hitung }}^{2}<X_{\text {hitung }}^{2}(1-\kappa)(k-1)$ dapat disimpulkan seluruh kelas memiliki variansi yang sama.

Sebelum menggunakan pengujian dengan statistik parametris, maka data penelitian yang diperoleh harus berdisribusi normal. Pada penelitian ini untuk mengetahui apakah data penelitian berdistribusi normal atau tidak digunakan uji normalitas rumus One Sample Kolmogorov-Smirnovdengan menggunakan program SPSS 16.0.

Menurut Riharjo (2011) uji normalitas rumus One Sample Kolmogorov-Smirnov bertujuan untuk menguji apakah dalam model regresi, variabel residu memiliki distribusi normal atau tidak. dengan kriteria pengambilan keputusan:

Jika nilai Asymp Sig (2-tailed) > 0,05 maka data berdistribusi normal.

Nilai Asymp Sig (2-tailed) < 0,05 maka data tidak berdistribusi normal. Jika data berdistribusi normal, maka uji statistik parametrik dapat dilanjutkan.

Untuk mengetahui hubungan Motivasi Belajar (X) dengan Hasil Belajar (Y), digunakan korelasi product moment:

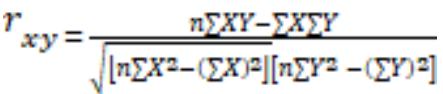

Sebelum menggunakan pengujian dengan statistik parametris, maka data penelitian yang diperoleh harus berdisribusi normal.

Hipotesis penelitian ini adalah:

$\mathrm{H}_{0}=$ Tidak terdapat hubungan yang signifikan antara Motivasi Belajar dengan Hasil Belajar siswa pada mata pelajaran fisika

$\mathrm{H}_{a}=$ Terdapat hubungan yang signifikan antara Motivasi Belajar dengan Hasil Belajar siswa pada mata pelajaran fisika.

Dengan menggunakan aplikasi SPSS 16.0 dapat dilihat seberapa besar pengaruh variabel indipenden terhadap variabel dipenden melalui tabel Correlation. Untuk memutuskan penerimaan hipotesis uji dapat dilihat dari nilai sig. (2-tailed). Jika Sig. (2-tailed) $<0,05$ maka tolak Ho.

Pada uji Hipotesis dengan korelasi Product Moment hanya dapat melihat hubungan variabel independen terhadap variabel dependen untuk data sampel. Untuk menguji signifikansi hubungan, yaitu apakah hubungan yang ditemukan itu berlaku untuk seluruh populasi yang berjumlah 650 siswa dapat dilihat dari rumus uji signifikansi korelasi product moment sebagai berikut:

$t=\frac{r \sqrt{n-2}}{\sqrt{1-r^{2}}}$

Dengan Hipotesis Uji:

Ho : Hubungan tidak signifikan

Ha : Hubungan signifikan

Dengan : $r=$ Koefesien korelasi $\mathrm{n}=$ Jumlah sampel

Menentukan nilai $\mathrm{t}_{\text {tabel }}$ yaitu, $\mathrm{t}_{(1-\alpha / 2)}$, dengan $\alpha=0,05$ dan $\mathrm{dk}=\mathrm{n}-2$. Adapun kriteria pengambilan keputusannya yaitu tolak Ho jika nilai mutlak $\left|t_{\text {hitung }}\right|>t_{\text {tabel }}$.

Dengan menggunakan aplikasi SPSS 16.0 uji hipotesis dapat dilakukan dengan melihat tabel Coeffecient. Dengan kriteria pengambilan keputusan tolak Ho jika nilai mutlak $\left|t_{\text {hitung }}\right|>t_{\text {tabel }}$.

\section{Hasil Penelitian dan Pembahasan}

Penelitian ini dilakukan di SMP Negeri di Kecamatan Jambi Selatan, dengan jumlah populasi keseluruhan 650 siswa, lalu ambil sampel sebanyak 191 dengan taraf kepercayaan 90\%. Untuk mendapatkan sampel ini terlebih dahulu dilakukan uji homogenitas untuk 
menguji apakah kelas sampel dalam populasi memiliki variansi yang sama. Dari hasil perhitungan, dapat disimpulkan bahwa siswa kelas VIII di SMP Negeri se-Kecamatan Jambi Selatan memiliki variansi yang sama. Karena kelas sampel memiliki variansi yang sama, maka pengambilan sampel dilakukan secara acak.

Dalam mengidentifikasi Motivasi Belajar yang dimiliki siswa, peneliti menggunakan angket motivasi belajar dengan $r$ tabel $=0,334<r_{11}=0,768$, yang digunakan oleh Nababan, Defi Elfrisa (2014) dengan kategori rebilitas tinggi dan sudah diuji validitasnya. Instrumen angket ini terdiri dari 25 menggunakan skala Likert dengan alternatif jawaban yang disediakan yaitu selalu (4), sering (3) ,jarang (2) dan tidak pernah (1). Pemberian bobot penilaian tersebut digunakan untuk menjaring data yang diperoleh dari siswa selanjutnya dianalisis menggunakan rumus statistik yang digunakan dalam analisis data.

Sebelum instrumen tes hasil belajar digunakan dalam penelitian terlebih dahulu diuji cobakan kepada responden. Responden yang dipilih peneliti dalam hal ini adalah siswa kelas IX di SMP Negeri 6 Kota Jambi yang berjumlah 36 siswa/i. Uji coba instrumen tes hasil belajar dilaksanakan pada tanggal 05 Oktober 2016. Adapun hasil analisis data yang diperoleh adalah sebagai berikut.

Dari analisis data yang telah dilakukan dapat dilihat butir soal mana saja yang valid dan memiliki validitas sangat tinggi, tinggi, sedang, rendah maupun sangat rendah setelah melakukan uji validitas dapat dilihat bahwa soal yang di ujikan memiliki kriteria yang bervariasi dalam tingkatannya. Soal dengan tingkat validitas tinggi yaitu soal nomor 35, soal dengan tingkat validitas cukup tinggi yaitu soal nomor $9,10,11,16,17,18,19,20,21,22,23$, $24,25,30,31,32,33$, dan 34, soal dengan tingkat validitas rendah yaitu soal nomor 1,2 , 5,14 , dan 15 , serta soal yang memiliki tingkat validitas sangat rendah yaitu soal nomor $3,4,6$, 7 , 8, dan 12 . Uji validitas ini dilakukan untuk melihat seberapa besar tingkat ke-validitasan soal tersebut.

Dari analisis data yang telah dilakukan dapat dilihat tingkat reliabilitas instrumen soal dengan menggunakan motode Koder Richardson-20 (KR-20) didapat $\mathrm{r}_{11}=0,944$. Untuk jumlah responden $(\mathrm{n}=36)$ maka $\mathrm{dk}=$ 35, sehingga untuk taraf signifikansi 0,05 didapat $r_{\text {tabel }}=0,334$. Sehingga dapat disimpulkan bahwa butir soal reliabel karena $r_{11}$ $>r_{\text {tabel }}$, yakni 0,944>0,334.

Uji tingkat kesukaran suatu soal bertujuan mengetahui tingkat kesulitan soal yang digunakan untuk mengukur hasil pembelajaran. Adapun hasil analisis data yang telah dilakukan dapat dilihat data hasil uji tingkat kesukaran soal, dapat di lihat bahwa tingkat kesukaran terbagi menjadi tiga, yaitu sukar, cukup dan mudah. Yang termasuk dalam kategori mudah yaitu soal nomor 9, 10, 11, 12, $14,15,27,30,31$, dan 32. Soal yang termasuk dalam kategori cukup yaitu soal nomor $1,3,4$, $5,6,7,13,16,17,18,19,20,21,22,23,24,25$, 26, 28, 29, dan 33. Sedangkan soal yang termasuk dalam kategori sukar yaitu soal nomor 8, 34, dan 35 . Berdasarkan hasil uji tingkat kesukaran soal ini dapat di tarik kesipulan bahwa soal memiliki tingkat kesukaran yang bervariasi.

Dalam Sudjana (2008) analisis daya pembeda mengkaji butir-butir soal dengan tujuan untuk mengetahui kesanggupan soal dalam membedakan siswa yang tergolong mampu ( tinggi perstasinya) dengan siswa yang tergolong kurang atau lemah prestasinya. Artinya, bila soal tersebut diberikan kepada anak yang mampu, hasilnya menunjukkan prestasi yang tinggi dan bila diberiakan kepada siswa yang lemah, hasilnya rendah. Tes dikatakan tidak memiliki daya pembeda apabila tes tersebut diujikan kepada anak berprestasi tinggi, maka hasil nya rendah, tetapi bila diberikan kepada anak yang berprestasi rendah hasilnya lebih tinggi. Dan apabila diberikan kepada kedua kategori siswa tersebut maka hasil nya sama saja. Dengan demikian, tes yang tidak memiliki daya pembeda tidak akan menghasilkan gambaran hasil yang sesuai dengan kemampuan siswa yang sebenarnya .

Dari data hasil penelitian pada sampel yaitu siswa kelas VIII SMP Negeri SeKecamatan Jambi Selatanyang memiliki variasi yang sama, maka pengambilan sampel dilakukan secara acak. Yang telah dilakukan dengan menguji soal sebanyak 30 butir yang memiliki variasi tingkat kesukaran yang beragam dan telah di uji validitas soal .

Didapatkan bahwa dari 191 sampel terdapat 94 siswa yang memiliki motivasi belajar yang sangat baik, 76 siswa yang memiliki motivasi belajar baik, dan 10 siswa yang memiliki motivasi belajar yang kurang. 
Berikut diagram pie hasil motivasi belajar yang dimiliki siswa :

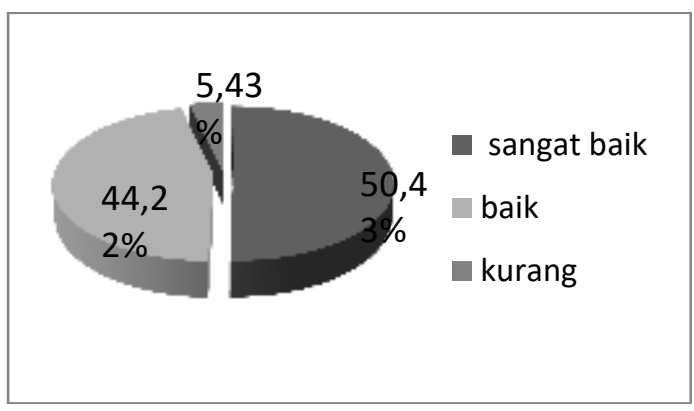

Gambar 4.1 hasil persentase dari 147 siswa

Berdasarkan Gambar 4.1 dapat dilihat bahwa dalam bentuk persentase $50,43 \%$ yang memiliki motivasi belajar sangat baik, 44,22 \% yang memiliki motivasi belajar baik dan 5,43\% yang memiliki motivasi belajar kurang.

Penelitian ini memiliki tujuan untuk mengetahui hubungan Motivasi Belajar dengan hasil belajar siswa pada kelas VIII. Untuk mengetahui adanya korelasi yang signifikan antara variabel bebas yaitu Motivasi Belajar (X) dengan variabel terikat yaitu hasil belajar siswa (Y).

Hipotesis yang dirumuskan akan diuji dengan menggunakan statistik parametris karna jumlah sampel lebih dari 30. Menurut Sugiyono (2009), untuk menganalisis data menggunakan statistik parametrik mensyaratkan bahwa data setiap variabel yang akan dianalisis harus berdistribusi normal. Dari analisis data penelitian menggunakan SPSS 16.0 didapat dilihat pada lampiran bahwa nilai Sig (2-tailed) $>\alpha$, yakni $0,356>0,05$ sehingga data berdistribusi normal. Karena data berdistribusi normal, maka analisis data menggunakan statistik parametrik dapat dilanjutkan.

Uji signifikan regresi dilakukan untuk mengetahui apakah hubungan antara variabel bebas dengan variabel terikat dapat diberlakukan untuk populasi. Adapun hasil perhitungan uji signifikansi regresi yang dilakukan dengan SPSS 16.0 untuk hubungan motivasi belajar dengan hasil belajar siswa adalah signifikan.

Menurut Trihendradi (2013), hubungan variabel dikatakan signifikan jika $\left|t_{\text {hitung }}\right|>t_{\text {tabel }}$ dan sig. $<0,05$. Dari analisis data menggunakan SPSS 16.0 untuk uji signifikansi hubungan motivasi belajar dengan hasil belajar diperoleh $\left|t_{\text {hitung }}\right|>t_{\text {tabel }}$ dan sig. $<0,05$ sehingga dapat disimpulkan bahwa motivasi belajar dengan hasil belajar adalah signifikan.
Dalam penelitian ini, peneliti menilai motivasi belajar siswa yang mencakup tentang Aktivitas belajar tinggi, Tekun dalam mengerjakan tugas, Ulet dalam menghadapi kesulitan, Respon siswa dengan adanya informasi dari guru, Respon siswa dengan adanya umpan balik, dan Respon siswa dengan adanya penguatan yang dimiliki oleh siswa kelas VIII Di SMP Negeri Se-kecamatan Jambi Selatan. Selain itu, peneliti juga mengukur kemampuan kognitif siswa pada materi Usaha dan Energi.

Setelah didapat skor angket, Dari hasil penelitian didapat 50,34\% atau terdapat 94 siswa yang memiliki motivasi belajar sangat baik, $44,22 \%$ atau 76 responden yang memiliki motivasi belajar baik, $5,43 \%$ atau terdapat 10 siswa yang memiliki motivasi belajar kurang. Sehingga dapat disimpulkan bahwa siswa kelas VIII SMP Negeri Se-kecamatan Jambi Selatan rata-rata memiliki Motivasi Belajar yang baik. Berikut adalah presentase hasil belajar yang di peroleh :

Tabel 4.5 Presentase Hasil Belajar

\begin{tabular}{lcc}
\hline Kategori & Persentase & $\begin{array}{c}\text { Jumlah } \\
\text { siswa }\end{array}$ \\
\hline Sangat kurang & $7,74 \%$ & 22 \\
Kurang & $1,36 \%$ & 3 \\
Cukup & $2,04 \%$ & 5 \\
Baik & $61,22 \%$ & 109 \\
Sangat baik & $27,89 \%$ & 52 \\
Jumlah & & 191 \\
\hline
\end{tabular}

Dari skor hasil belajar siswa dapat dikategorikan bahwa siswa memiliki hasil belajar yang baik. Setelah didapat skor angket dan tes hasil belajar siswa, kedua hasil skor angket motivasi belajar dan tes hasil belajar dianalisa dengan menggunakan analisis korelasi pearson untuk dapat menjawab hipotesis penelitian, yakni ada atau tidak hubungan yang signifikan antara motivasi belajar dengan hasil belajar siswa pada materi Usaha dan Energi. Dari hasil analisis data dengan menggunakan SPSS 16.0 diperoleh hasil Correlation $\mathrm{t}$ sebesar 0,356 . Uji hipotesis menggunakan $t_{\text {hitung }}$ diperoleh hasil 5,214 dan $\mathrm{t}_{\text {tabel }}$ dari tabel $\mathrm{t}$ sebesar 1,972. Karena $t_{\text {hitung }}>t_{\text {tabel }}$ maka $\mathrm{H}_{0}$ ditolak, artinya ada hubungan yang signifikan antara motivasi belajar dengan hasil belajar.

Dari hasil penelitian yang diperoleh, motivasi belajar memiliki hubungan yang 
signifikan dengan hasil belajar yang diperoleh oleh siswa. Oleh karena itu, akan lebih baik jika dalam menyampaikan materi pembelajaran guru memperhatikan motivasi belajar yang dimiliki oleh setiap siswa. Hal ini sejalan dengan pendapat Dalyono (2005) yang memaparkan bahwa motivasi adalah daya penggerak/ pendorong untuk melakukan sesuatu pekerjaan,yang berasal dari dalam diri dan juga dari luar siswa untuk dapat mengendalikan diri dalam belajar dan harus mempunyai jiwa kepemimpinan karna itu dapat meningkatkan kecerdasan dalam diri untuk maju serta dapat mencapai kesuksesan yang baik, dalam bidang akademik maupun sosialnya. Hal ini karna dalam pengelolaan diri tersebut terdapat motivasi serta rasa ingin tahu yang tinggi sehingga memungkinkan untuk dapat meningkatkan hasil belajar di sekolah.

Menurut Kadarsih (2012), motivasi belajar juga dapat diartikan sebagai dorongan yang memungkinkan siswa untuk bertindak dan melakukan sesuatu". Seorang guru harus dapat menunjukkan pentingnya pengalaman dan materi belajar bagi kehidupan siswa, dengan demikian siswa akan belajar bukan hanya sekedar untuk memperoleh nilai atau pujian akan tetapi didorong oleh keinginan untuk memenuhi kebutuhannya. Guru sebagai seorang pendidik merupakan salah satu 'pembawa perubahan' yang sangat berperan dalam proses pembelajaran di sekolah. Dalam pembelajaran seorang guru harus dapat melihat motivasi belajar siswa yang meliputi bagaimana mereka mengerjakan tugas, keaktifan dalam kelas, respon terhadap pertanyaan guru, dan respon siswa terhadap feedback yang di berikan siswa lainnya.

Hal ini dapat terwujud dengan menyediakan lingkungan yang kondusif, menciptakan iklim pembelajaran yang demokratis, mengembangkan sikap empati, merasakan apa yang dirasakan oleh siswa, melibatkan siswa secara optimal dalam pembelajaran, baik secara fisik, sosial maupun emosional dan lain sebagainya. Kondisi yang kurang terolah juga dengan mudah menyebabkan siswa lain itu kadang sangat bersemangat menyetujui sesuatu, tetapi dalam waktu singkat berubah menolaknya, sehingga mengacaukan kerjasama yang disepakati bersama teman-teman lainnya. Maka, kerjasama yang telah dilakukan itu cenderung akan mengalami kegagalan..
Ini berarti orang yang baik memotivasi diri akan dapat menampilkan kemampuan sosialnya, dengan kata lain motivasi belajar seseorang terlihat dari tingkah laku yang ditunjukkannya. Asumsi ini diperjelas oleh pendapat Wiyono dalam Ekawarna (2009) yang menjelaskan bahwa seseorang yang memiliki motivasi belajar tinggi akan melakukan kegiatan belajar secara optimal.

\section{Simpulan dan Saran}

\section{Simpulan}

Berdasarkan hasil penelitian yang telah dilakukan, maka diperoleh kesimpulan sebagai berikut. Dengan melakukan uji hipotesis menggunakan korelasi produck moment melihat hubungan variabel independen terhadap variabel dependen didapat nilai $t_{\text {hitung }}$ sebesar 5,214 dan $t_{\text {tabel }}$ sebesar 1,972. Karena $t_{\text {hitung }}>t$ tabel atau 5,214>1,972 maka $\mathrm{H}_{0}$ ditolak dengan taraf signifikansi $\alpha=5 \%$. Sedangkan nilai koefisien yang didapat dari hasil pengolahan menggunakan SPSS.16 diperoleh nilai sebesar 0,356 . Dalam hal ini nilai tersebut termasuk pada katagori korelasi lemah atau dapat dikatakan ada korelasi antara motivasi belajar dengan hasil belajar tetapi lemah. Dan dari hasil SPSS terdapat hubungan yang signifikan antara motivasi belajar dengan hasil belajar siswa kelas VIII di SMP Negeri Sekecamatan Jambi Selatan.

\section{Saran}

Berdasarkan hasil penelitian mengenai hubungan motivasi belajar dengan hasil belajar pada siswa kelas VIII Se-kecamatan Jambi Selatan: 1) Bagi siswa, diharapkan siswa kelas VIII Se-kecamatan Jambi Selatan bisa mengenali diri, memotivasi diri sendiri, motivasi oran lain, dan meningkatkan motivasi dalam belajar, sehingga dengan mengendalikan diri sendiri kita bisa meningkatkan kecerdasan diri dan menerima pelajaran dengan baik, mengolah serta memproses materi pembelajaran dan mengoptimalkan hasil belajarnya. 2) Bagi guru bidang studi fisika kiranya dapat memperhatikan aspek emosional siswa dalam proses pembelajaran, sehingga dapat merangsang siswa untuk belajar secara maksimal serta dapat membantu perkembangan aspek-aspek motivasi belajar siswa seperti kesadaran diri, pengaturan diri empati dan keterampilan sosial. 3) Bagi peneliti 
selanjutnya, penelitian ini memiliki banyak keterbatasan, seperti dalam pengambilan data hasil belajar sebaiknya menggunakan seluruh mata pelajaran sehingga hasil yang didapat merupakan prestasi belajar yang kompleks, Sampel penelitian diperbanyak agar hasil yang diperoleh betul betul representatif. Selain itu variabel yang digunakan bisa diperbanyak dengan menggunakan motivasi-motivasi lain.

\section{Daftar Pustaka}

Abdurrahman, M, 2003. Pendidikan Bagi Anak Berkesulitan Belajar. Jakarta: Rineka Cipta

Arikunto, S. 2009. Dasar-dasar Evaluasi Pendidikan. Jakarta: Bumi Aksara

Arikunto, S, 2010. Prosedur Penelitian suatu Pendekatan Praktik. Jakarta: Rineka Cipta

Aryana, Safititri. 2003. Psikologi Pendidikan Dengan Pendekatan Baru. Bandung: Remaja Rosda Karya.

Budiadnya, Made. 2006. Uji coba Model Pembelajaran Generatif dalam Pembelajaran Pendidikan Pancasila dan Kewarganegaraan (PPKn) di SMP Negeri 5 Singaraja. Tesis. Singaraja: Program Pascasarjana IKIP Negeri Singaraja.

Dimyati dan Mudjiono. 2010. Belajar dan Pembelajaran. Jakarta: Rineka Cipta.

Djamarah, Syaiful Bahri, 2002. Psikologi Pendidikan, Jakarta, PT. Rineka Cipta.

Ekawarna. 2009. Penelitian Tindakan Kelas. Jakarta: REFERESI (GP Press Group).

Ekawarna. 2013. Penelitian Tindakan Kelas. Jakarta: REFERESI (GP Press Group).

Hamalik, Oemar. 2013. Proses Balajar Mengajar. Jakarta: Bumi Aksara.

Hamzah, B. Uno. 2013. Teori Motivasi dan Pengukurannya. Jakarta: Bumi Aksara.
Hanafiah dan Suhana. 2012. Konsep Strategi Pembelajaran . Bandung: PT Refika Aditama

Hanafiah, dkk. 2012. Hubungan Motivasi Belajar Dan Kepercayaan Diri Dengan Kemampuan Kognitif Siswa Pada Mata Pelajaran Fisika Kelas X Negeri Kebak Kramat. Diakses Dari: Eprituns.ac.id/21873/pdf. Pada tanggal 10 September 2015.

Hartini, Mimin. 2010. Model dan Teknik Penilaian pada Tingkat Satuan Pendidikan. Jakarta: Gaung Persada Press.

Hidayat, M. 2013. Pembelajaran Discovery Strategi dan Mental Vocational Skill. Yogyakarta: Diva Press.

Kadarsih, 2012. Power Full in Educating. Yogyakarta: Araska, Pinang Merah Residence.

Nababan, Devi Elfrisa, (2014). Penerapan Model Pembelajaan ARIAS Terintegratif Untuk Meningkatkan Motivasi Belajar Fisika Siswa Kelas XI.MIA 1 SMA Negeri 6 Kota Jambi, Skripsi, Universitas Jambi, Jambi.

Purwanto. 2010. Evaluasi Hasil Belajar. Yojgakarta: Pustaka Belajar

Raharjo, 2011. Pengaruh Kecerdasan Emosional, Kecerdasan Spiritual Dan Prestasi Belajar Kelas X SMK Negeri 1 Dlanggu Kabupaten Mojokerto, Skripsi : Universitas Islam Negeri Maulana Malik Ibrahim.

Riduwan. 2012. Belajar Mudah Penelitian untuk Guru-Karyawan dan Peneliti Pemula. Bandung: Alfabeta.

Sagala, Erman. 2013. Strategi Pembelajaran dan Mengajar Kontemporer. Bandung: Alfabeta

Slameto, 2010, Belajar dan Faktor-Faktor Yang Mempengaruhi, Jakarta: Rineka Cipta.

Sugiyono. 2009. Metode Penelitian Pendidikan Pendekatan Kuantitatif, Kualitatif dan $R \& D$. Bandung: Alfabeta

Sudjana, Nana. 2008. Penilaian Hasil Proses Belajar Mengajar. Remaja Rosdakarya: Bandung 
Suprijono, Agus. 2010. Cooperative Learning. Yogyakarta: Pustaka Pelajar

Sudijono, Amanah 2008 . HubunganAntara

Kecerdasan Emosional Dengan Prestasi Belajar Pada Siswa Kelas II SMU Lab SchoolJakarta Timur. Jakarta : Universitas Persada Indonesia.

Trihendradi, Cornelius. 2013. Step By Step IBM SPSS 21 : Analisis Data Statistik. Penerbit CV. Andi Offset Yogyakarta.

Zainul. 2007. Desain Pendidikan karakter: Konsepsi dan Aplikasinya dalam Lembaga Peendidikan. Jakarta : Belajar 